Will to Live 



\title{
Will to Live
}

\begin{abstract}
AIDS THERAPIES AND
THE POLITICS OF SURVIVAL
\end{abstract}

João Biehl

Photographs by Torben Eskerod

PRINCETON UNIVERSITY PRESS

PRINCETON AND OXFORD 
Copyright $@ 2007$ by Princeton University Press

Published by Princeton University Press, 41 William Street, Princeton, New Jersey 08540

In the United Kingdom: Princeton University Press, 6 Oxford Street, Woodstock, Oxfordshire OX20 1TR

All Rights Reserved

Paper ISBN: 978-0-691-14385-9

Cloth ISBN: 978-0-691-13008-8

Library of Congress Control Number: 2007934333

British Library Cataloging-in-Publication Data is available

Publication of this book has been aided by Princeton University's Committee on Research in the Humanities and Social Sciences

Printed on acid-free paper. $\infty$

press.princeton.edu

Printed in the United States of America

$\begin{array}{llllllllll}10 & 9 & 8 & 7 & 6 & 5 & 4 & 3 & 2 & 1\end{array}$ 
For my parents 

And from this indigent river, this blood-mud that meanders with its almost static march through sclerosis and cement

and from the people who stagnate in the river's mucus, entire lives rotting one by one to death,

you can learn that the human being is always the best measure, and that the measure of the human is not death but life.

- João Cabral de Melo Neto, Education by Stone 
